BERITA KHUSUS ANDA :

PERANAN QUALITY CONTROI DALAN MODERN PACKAGING Oleh :

Ir. Edi Witojo Kaswadi M.S.E.A.

(Paper Dalam Seminar Container Tanggal 18 - 20 Maret 1974 di Jakarta)

\title{
ABSTRACT
}

The characteristics of modern packaging are standard of volume size or package weight and contents, filling process and design of package.

In the field of modern packaging, the role of quality control are in the optimal total standard packaging size, in the filling process and labelling, and in the determination of optimal packaging size which can be handled or transported efficiently.

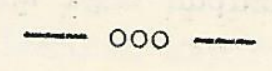

Modern Packaging pada waktu sekarang ini dicirikan oleh beberapa ciri tertentu antara lain yaitu adanya standar-standar tertentu mengenai ukuran volume atau berat bungkus/package maupun produk yang ada didalamnya dan dipergunakan dalam perdagangan ataupun distribusi produk dalam jumlah yang banyak.

Disamping itu ada ciri lain dalam modern packaging yaitu proses pengisian package tersebut biasanya dila- 
kukan dengan kecepatan yang tinggi dimana diperlukan suatu penyetelan "filling-machine" secara cermat agar jumlah produk yang dimasukkan kedalam package tersebut tidak terlalu/kurang sedikit dari yang seharusnya sebagaimana tercantum didalam label dari package tersebut, sehingga akan merugikan konsumen yang membelinya ataupun juga tidak lebih banyak dari pada yang sehamusnya sebagaimana tercantum pada label package sehingga merugikan pihak produsen sendiri.

Ciri lain lagi dari pada modern packaging yaitu package tersebut didesign dengan tujuan dapat secara effisient dihandle atau ditransportasikan dari satu ke lain tempat serta dapat merupalian pelindung yang ekonomis dan cukup baik bagi produk yang disimpan didalamnya. Dari uraian singkat tentang ciri modern packaging tersebut diatas jelaslah tampak peranan Quality Control (pengendalian mutu) didalam mencapai usaha dan tujuan packaging yang optimum baik bagi produsen cari produk yang dibungkusnya, maupun bagi konsumen yang membeli produk tersebut.

Marilah sekarang kita bahas satu-persatu peranan Quality Control dalam modern packaging sesuai dengan ciri-ciri tersebut diatas.

1. Peranan Quality Control Dalam Jumlah Standar Ukuran Package Yang Optimum.

Agar sesuai dengan kemampuan membeli konsumen yang berbedambeda yanf tercermin didalam consumption patterm di Indonesia dimana percapita income keluarga sangat bervariasi dari yang terendah $\pm R p \cdot 6.000,-$ 
sebulan sampai $\pm R p \cdot 1.000 .000,-$ sebulan atau lebih, maka produsen harus sanggup mengetahui consumption pattern tersebut.

Memang makin banyak jumlah ukuran package yang dipergunakan, makin Iuweslah untuk menyesuaikan penjualan barang dengan consumption pattern tersebut, tetapi makin banyak macam standar ukuran package yang dipergunakan, biaya produksi dan bulk packaging serta distribusi selanjutnya praktis akan lebih mahal per-unit packagingnya.

Sedangkan kalau jumlah standar ukuran sedikit ada range/level, dari income group yang kurang cocok densan daya belinja, sehingga menimbulkan semacam negative reaction atau kekecewaan ataupun keengganan untuk membeli produk dengan ukuran volume/berat tertentu jang harganya tak sesuai dengan kemampuannya, maka dalarn hal ini timbullah apa yang disebut "adaptation Ioss".

Untuk mengatasi hal-hal tersebut diatas, maka produsen dapat melakukan experimen dan sampling data dipasaran yang dapat dipergunakan untuk memperkirakan jumlah standar vkuran yang acceptable dimasyarakat Indonesia. Untuk jelasnya maka berikut ini disampaikan diagram model untuk analisa secara sederhana. 


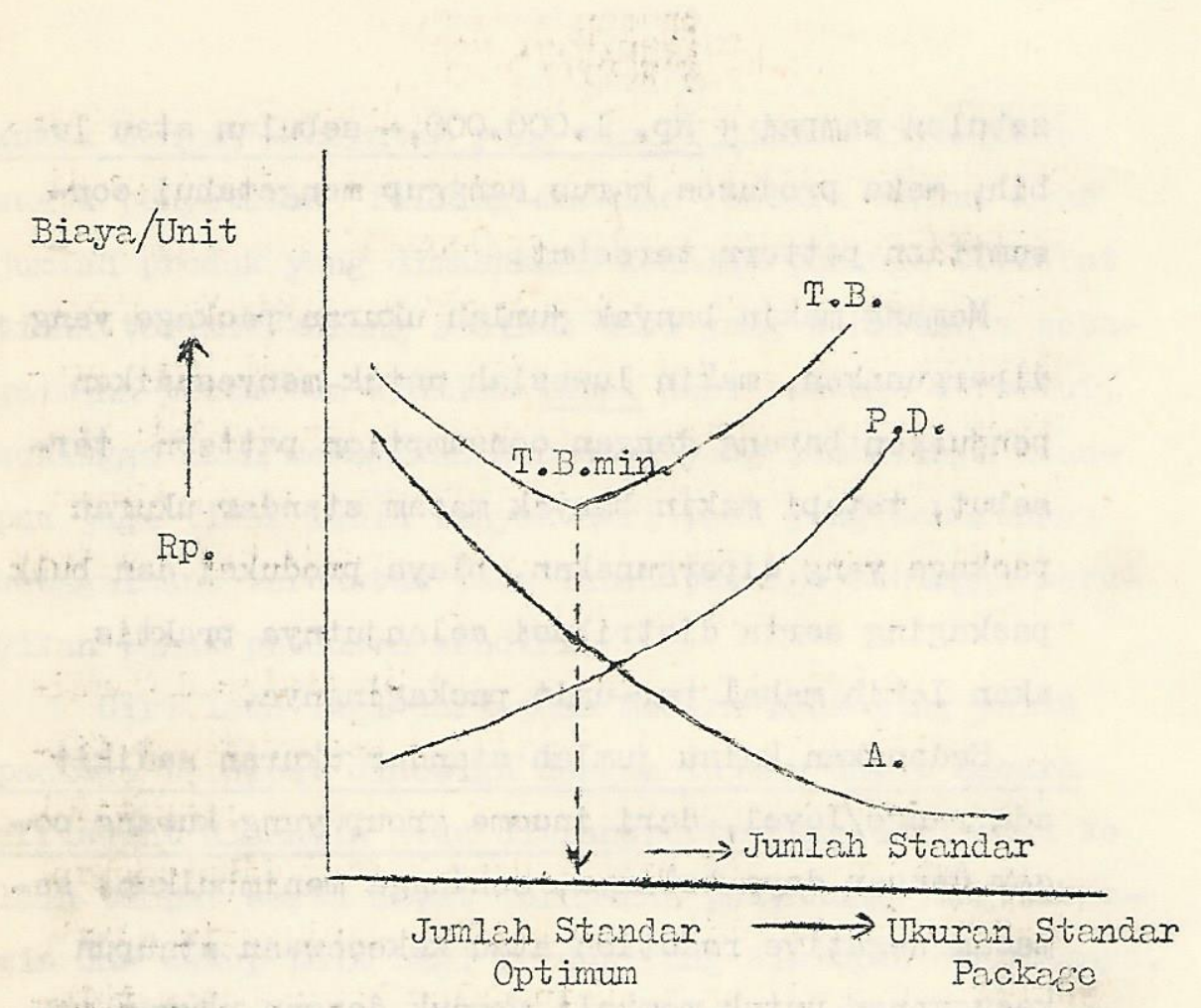

\section{Keterangan :}

$T_{0} B_{0}=$ Total Biaya per Unit.

$\mathrm{P}_{0} \mathrm{D}_{0}=$ Biaya Produksi dan Distribusi per Unit。

A. = Kerugian Adaptasi per Unit.

2. Peranan Quality Control Didalam Proses Filling Machine Dan Label.

Filling machine ini biasanya dijalankan secara otomatis atau semi otomatis dan terdiri dari beberapa filling head sckaligus (misalnya pengisian mentega, susu kaleng, kopi, limun, dan sebagainya).

Agar tak terjadi penyimpangan jumlah produk yang diisikan oleh filling head-filling head, maka perlu dicatat hasil pengisian produk oleh filling head tersebut, kemudian dibuat analisa process 
control dengan process chart analysis dan sebagainya secara sampline untuk mengetahui bila terjadi perubahan didalam pengisian/kapabilitas dari filling machine atau filling headnya, sehingga dapat dicegah hal-hal yang tak diinginkan baik oleh produsen maupun konsumen, terutama kalau terjadi pelanggaran Undang-Undang (Peraturan Barang) dinana isi package ternyata tak sesuai dengan yang tertera pada label package tersebut.

Dengan mempergunakan analisa Statistical Quality control kita dapat mengetahui secara tepat filling machine mana dan filling head mana yang tidak baik kerjanya, hal mana kadang-kadang dihubungkan juga dengan "machine capability" dari suatu alat untuk menghasilkan sesuatu dalam batas-batas toleransi yang diizinkan/diinginkan.

3. Peranan Quality Control Dalam Menentukan Ukuran Optimum Yang Dapat Dihandle Atau Ditransportasi Secara Effisient.

Pada modern packaging ukuran package ini sangat penting, yaitu dikehendaki adanya package dalam jumlah banyak yang betul-betul sama besarnya asar filling machine tidak macet (misalnya pengisian botol bier, limun dan sebagainya, penting bahwa tinggi botol dalam batas toleransi tertentu dan volumenya demikian pula, agar mesin tak macet dan tak ada effek psikologis negatif atas appearence isi botol yang berbeda).

Disamping itu ukuran berat/isi package penting 
dalam hubungannya dengan kemampuan optimum manusia mengangkat barang, hal mana dapat diteliti dengan mensgunakan "orgonomics" atau "motion and time study ${ }^{\text {r7 }}$ misclnya didalam menentukan beratnya satu bungkus semen yang optimum adalah $+45 \mathrm{~kg}$, dan sebagainya.

Dapat juga ukuran package ditetapkan sesuei dengan kemampuan alat transpor yang akan dipergunakan. 